\title{
Melipona GARBAGE BEES RELEASE THEIR CARGO ACCORDING TO A GAUSSIAN DISTRIBUTION
}

\author{
KERR, A. S. ${ }^{1}$ and KERR, W. E. ${ }^{2}$ \\ ${ }^{1}$ Institute of Physics, Dept. Applied Physics, University of São Paulo, CEP 05508-900, São Paulo, SP, Brazil \\ ${ }^{2}$ Federal University of Uberlândia, Dept. Genetics and Biochemistry, CEP 38400-902, Uberlândia, MG, Brazil \\ Correspondence to: Warwick Estevam Kerr, Federal University of Uberlândia, Dept. Genetics and Biochemistry, \\ CEP 38400-902, Uberlândia, MG, Brazil \\ Received August 08, 1996 - Accepted September 09, 1998 - Distributed February 23, 1999
}

(With 1 figure)

\begin{abstract}
Worker bees of Melipona compressipes and Melipona scutellaris (Meliponinae, Apidae) colonies, involved in carrying garbage to the outside of the nest, dump each individual load cargo of cocoon pellets (cocoon + larval feces + remaining wax). For Melipona scutellaris they weight a mean of $27.8 \mathrm{mg}$, and are dropped at a distance of 1 to $45 \mathrm{~m}$ and between 1 and $35 \mathrm{~m}$ for $M$. compressipes, according to a Gaussian Distribution. In the case of M. scutellaris the expression is:

$N(x)=b x+\frac{A}{\sigma \sqrt{2 \pi}} \operatorname{Exp}\left[\frac{-(x-\langle x\rangle)^{2}}{2 \sigma^{2}}\right]$ where,

$N(x)=$ number of pellets; $\operatorname{Exp}=e$ elevated to the expression in brackets; $x=$ distance in meters; the linear term $(b x)$ describes accidental cargo slipping.

The constants for the observed data are: $b=0.69 ; A=1363 ; \sigma=2.16 \mathrm{~m} ;\langle x\rangle=32.14 \mathrm{~m}$.

Evolutionary aspects of this method of disposal of garbage are discussed.

Key words: stingless bees, Melipona scutellaris, Melipona compressipes, garbage bees, Gaussian Distribution, garbage release.
\end{abstract}

\section{RESUMO}

\section{Abelhas lixeiras de Melipona soltam suas cargas conforme uma distribuição normal}

As operárias lixeiras de Melipona compressipes e Melipona scutellaris (Meliponinae, Apidae) soltam sua carga de casulo + fezes + cera (que pesa em média $27.8 \mathrm{mg}$, em Melipona scutellaris) a distância de 1 a 35 m para Melipona compressipes e de 1 a 45 para Melipona scutellaris, de acordo com uma Distribuição Gaussiana. Para o caso de Melipona scutellaris a expressão é :

$N(x)=b x+\frac{A}{\sigma \sqrt{2 \pi}} \operatorname{Exp}\left[\frac{-(x-\langle x\rangle)^{2}}{2 \sigma^{2}}\right]$ em que,

$N(x)=$ número de cargas; $\operatorname{Exp}=e$ elevado à expressão entre colchetes; $x=$ distância em metros; o termo linear $(b x)$ expressa escorregamentos acidentais de carga.

Foram determinadas as seguintes constantes para os dados observados: $b=0,69 ; A=1363, \sigma=2,16 \mathrm{~m}$; $\langle x\rangle=32,14 \mathrm{~m}$. Foram discutidos aspectos evolutivos desse método de lidar com o lixo.

Palavras-chave: abelhas sem ferrão, Melipona scutellaris, Melipona compressipes, abelhas lixeiras, Distribuição Gaussiana. 


\section{INTRODUCTION}

Comparative studies of biological activities of stingless bees are important to the understanding of the phylogeny among the groups. The releasing of the garbage to the outside of the hives differs considerably in different species of bees. Apis mellifera bees (Apidae, Apinae) defecate outside the hive (except for the queen). Stingless bees (Apidae, Meliponinae) defecate within the hive and these feces are brought by garbage bees in two stages to the outside.

Bees of the subfamily Meliponinae live inside a sealed waxy alveolus from the egg till the prepupal stage. At the end of the larval phase each larva weaves a thin silk cocoon. This silk lines the interior of the wax cell. Adult worker bees remove the wax from cocoon in order to employ it in other constructions and also for allowing more air to filter through the silk for the pupa. Some wax plus the silk cocoon and the feces produced by the prepupa before pupating are left behind at emergence.

The bee tears the superior part of the cocoon, emerges, and begins its adult life. For three to four days this worker stays on the brood comb heating larvae and pupae.

Between the 9th and 14th day they build new wax cells and provision them with pollen, honey and glandular food for the queen both to eat a little and to oviposit. At around 18 to 20 days of age, the bees become garbage collectors within the hive. These workers remove each used cocoon, and place it on a garbage mound within the nest. At about 25 days of age, the workers begin the labor of taking these cocoon pellets (comprised of cocoon silk + feces + wax) out of the hive (Kerr et al., 1996).

Workers of Lestrimelitta limao release all garbage directly from the hive entrance and workers of Frieseomelitta varia do it within less than one meter of the hive. Observation of some Melipona compressipes hives gave us the impression that they dispersed the compound pellet cargo (cocoon + wax + feces) under a mathematical pattern. An enormous quantity of beauty in nature follows mathematical rules.

The formation of the figures of shells and snails has been recently studied by Meinhard (1995). The objective of this paper is to find out if our hypothesis is actual and if it contains an evolutive explanation.

\section{MATERIALS AND METHODS}

Twenty hives of Melipona compressipes were used in São Luis, MA, Brazil (2 ${ }^{\circ} 31^{\prime}$ S; $44^{\circ} 16^{\prime} \mathrm{W}$ ) in 1986, and 20 of Melipona scutellaris, in Uberlândia, MG, Brazil (18 ${ }^{\circ} 56^{\prime}$ S, $48^{\circ} 18^{\prime} \mathrm{W}$ ) in 1993. Both in São Luis and Uberlândia the hives were arranged on a three floors shelf, in a same vertical plan. The measurements of the distances were taken from the center of the base of the shelf to the mark of a melted wax dropped in a long one meter wide paved way. A first measurement of the weight of 20 complete sets of cocoon + feces + wax was $576 \mathrm{mg}$ (each weight $28.8 \mathrm{mg}$ ). A second measurement collected the following data: 5 sets of cocoon + feces + wax before taken to the garbage mound weight $184 \mathrm{mg}$ (1 alveolus weight $36,8 \mathrm{mg}$ ). The weight of five sets of cocoons with $50 \%$ of their heights cut in the process of the releasing of the alveoli from the combs and transportation to the garbage mound was 139 $\mathrm{mg}(1$ cell $=27,8 \mathrm{mg})$. Watchings were also made in three nests of Lestrimelitta limao and two of Frieseomelitta varia.

Our data were analyzed with the help of the Origin V.4.0 Program (from the Microcal Software, Inc.).

\section{RESULTS}

The workers of Melipona scutellaris release their cargo of cocoon + feces + wax to a certain distance from the colony. The sun melts the wax of the pellets leaving in the cement paved soil a characteristic dark mark.

In 1986, flying garbage bees of Melipona compressipes were seeing releasing the cargo (cocoon + feces + wax) between 1 to $35 \mathrm{~m}$ distant. Two sets were released at smaller distances than three meters, 10 were released between 23 and $30 \mathrm{~m}$, and one between 30 and $35 \mathrm{~m}$ from the hive. About 800 were released between seven and $23 \mathrm{~m}$, with a media in $18 \mathrm{~m}$. This configuration of cargo releasing indicates that garbage bees of this species might release the comb residues at a standard distance subjected to a random variation due to both imprecision of evaluation of the workers about the position where it is and to eventual escapement of the cargo.

In 1993, this type of observation was repeated with Melipona scutellaris. The number of 
melted pellets marks in the soil and their respective distances to the colonies were quantified with more data and more precision. The results are in Table 1. Some larvae that were killed by an unusual cold, in two days, when external temperature decreased to $1{ }^{\circ} \mathrm{C}$ and $2{ }^{\circ} \mathrm{C}$, and weighed 120 to $160 \mathrm{mg}$ were released from 0,5 to $5 \mathrm{~m}$; they are very smooth and felt easily from the bee mandibles. In this case, the same or another bee takes it and releases it 10 to $15 \mathrm{~m}$ far.

The average distance $(\langle x\rangle)$ of garbage release in the data of Table 1 is $30.9 \mathrm{~m}$ with standard deviation $(\sigma)$ of $5.2 \mathrm{~m}$. The points of release carried out at $16 \mathrm{~m}$ or less are at more than $2.95 \sigma$ from the average and therefore, they have a probability of $0.42 \%$ or less of belonging to this distribution. They may be considered as atypical, caused by badly succeeded transportation, that is, the worker left the cargo to slip before time; this allow us to estimate a new media and error for the all other points: $\langle x\rangle=31.9 \mathrm{~m}$ and $\sigma=2.8 \mathrm{~m}$.

The distribution was analyzed adjusting it through a Gaussian function for all points, using the least squares method. The expression fitted was:

$N(x)=b x+\frac{A}{\sigma \sqrt{2 \pi}} \operatorname{Exp}\left[\frac{-(x-\langle x\rangle)^{2}}{2 \sigma^{2}}\right]$

where $N(x)=$ number of cocoon pellets; $x=$ distance in $\mathrm{m} ; \operatorname{Exp}=$ the base of Natural Logarithm $(e=2.71828 \ldots)$ elevated to the exponent inside the brackets; the linear term $(b x)$ describes the accidental cargo slipping.

The data fitted for the observed data are: $b=0.69 \pm 0.22 ; A=1363 \pm 96 ; \sigma=$ standard deviation $=2.16 \pm 0.13 \mathrm{~m} ;\langle x\rangle=$ mean distance $=$ $32.14 \pm 0.10 \mathrm{~m}$. The correlation coefficient was $0.994(\mathrm{P}<0,001)$.

\section{DISCUSSION}

Bees have a great quantity of biological data that were naturally selected and that fit mathematical equations and curves that likely are the ones that provide them the best adaptability (Darwin, 1859; Vogt, 1911). In the present case one concludes that, except for cargo that slipped before and fell occasionally, the workers of Melipona scutellaris release the set of cocoon (plus larval feces and a small quantity of wax) according to the normal distribution term in the Equation 1.
Furthermore at Fig. 1 it can be seen a smoothly increasing background. These points were fitted by the linear term $(b x)$, in Equation 1. It means that the chance of happen an accidental releasing, during the fly, increases linearly with the distance from the hive.

The functional fitting provided a useful way to analyze our data, since it simplifies the test of different hypothesis. Either a pure Gaussian or a Gaussian plus a constant or a linear term, provided good fit to the Melipona scutellaris data set. The Gaussian term is evidently dominant, although the inclusion of the linear term provided the best correlation and biological interpretation. It enabled to distinguish between dump or slipping of the garbage, and the calculation of the specific constants of each process. The mean and standard deviation, in this case, are obtained as parameters of the adjusted function and are very close to the values obtained, with the exclusion of the atypical points $(x<16 \mathrm{~m})$.

This strengthens the qualitative visual observation that Melipona compressipes workers also release their cargoes according to this type of distribution, being possible to estimate the parameters associated to their Gaussian curve even from the few data that were collected for this species. The mean is around $18 \mathrm{~m}$. It should be remembered that this is a bee stronger than Melipona scutellaris, that had a mean of $32.1 \mathrm{~m}$. From a total of 820 pellets, 800 were concentrated in $16 \mathrm{~m}$ that is, $97.6 \%$ of all cases, given a $\sigma=3.54 \mathrm{~m}$.

This characteristic of releasing their cargo according to a Gaussian distribution is not general to all meliponid species; workers of Lestrimelitta limao, the pirate bee for instance, release the garbage right in front of the hive. Frieseomelitta varia workers release all the garbage in less than $1 \mathrm{~m}$. In some species the workers release the garbage to the outside very near to their own nest. Among the bad consequences that such behavior may bring are:

a) May attract the terrible enemy Pseudohypocera kerteszi (Diptera, Phoridae).

$b$ ) The garbage may alert the carnivore irara (Eira barbara, Mustelidae) that usually destroy the nest to eat the honey, pollen, brood and bees.

c) In case of disease, these species will maintain a focus of it very near to the colony for a longer time. 
TABLE 1

Distribution of cocoon pellet drops by Melipona scutellaris along a long paved walk.

\begin{tabular}{|c|c|c|c|}
\hline $\begin{array}{c}\text { Position intervals } \\
\text { (class intervals) } \\
\text { (m) }\end{array}$ & $\begin{array}{l}\text { Interval center } \\
\text { (class mark) } \\
(\mathbf{m})\end{array}$ & Frequency of pellets & Fitted \\
\hline $0-1$ & 0.5 & 0 & 0 \\
\hline $1-3$ & 2 & 1 & 1 \\
\hline $3-4$ & 3.5 & Grass (1) & 2 \\
\hline $4-6$ & 5 & 7 & 3 \\
\hline $7-11$ & 9 & Grass (1) & 6 \\
\hline $11-13$ & 12 & 7 & 8 \\
\hline $13-15$ & 14 & 18 & 10 \\
\hline $15-17$ & 16 & 16 & 11 \\
\hline $17-23$ & 20 & Roof and grass (1) & 14 \\
\hline $23-25$ & 24 & 19 & 17 \\
\hline $25-27$ & 26 & 21 & 22 \\
\hline $27-29$ & 28 & 68 & 59 \\
\hline $29-31$ & 30 & 176 & 175 \\
\hline $31-33$ & 32 & 263 & 273 \\
\hline $33-35$ & 34 & 216 & 197 \\
\hline $35-37$ & 36 & 52 & 76 \\
\hline $37-39$ & 38 & 34 & 33 \\
\hline $39-49$ & & Street (1) & \\
\hline
\end{tabular}

(1) There was no possibility to count the pellets felt in these places since the wax does not melt on this type of substrate and change of places with the wind.

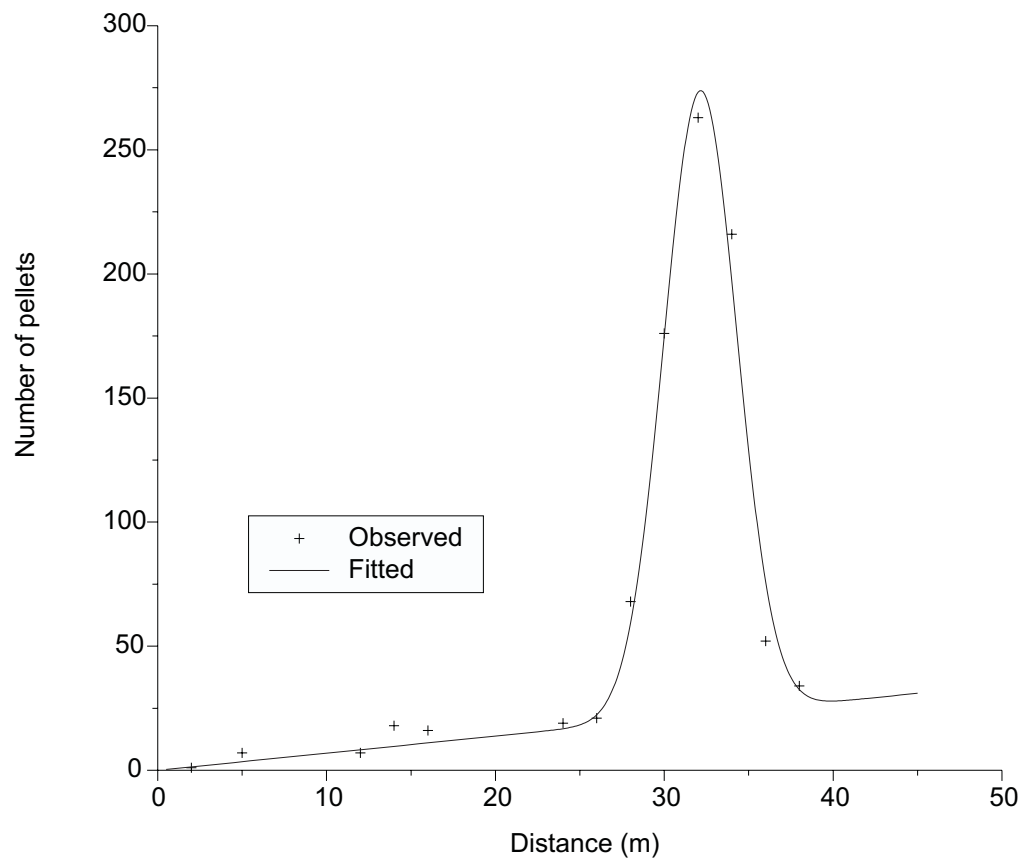

Fig. 1 - Gaussian Distribution plus a linear term $(b x)$ that fits observed values of garbage pellets (wax + feces + cocoons) released by worker bees of Melipona scutellaris throughout an axis from the hive to 40 meters. Data in page 121. 
The only apparent advantage is the expending of less energy.

Otherwise, the behavior of throwing the garbage far from the nest brings the following considerations.

1. The items $a, b$ and $c$ listed above are eliminated or diminished.

2. After a given distance there is no more selective advantage and the bee only wastes energy and time. Therefore they should be selected to the best distance.

These points give to the Melipona behavior an adaptive value. The genus Melipona is among the Meliponinae the one with the greatest number of species (about 50, while Trigona has about 25) and occupy a great number of ecological niches. In addition to the system of caste determination, this type of garbage disposal differentiates Melipona species from other genera of stingless bees.
Acknowledgments - The authors thank the CNPq (Brazilian Council for Research and Development), FAPEMIG (Research Foundation of the State of Minas Gerais) and the Bank of Brazil Foundation, for the financial help that allowed us to have a collection of 75 hives of Melipona compressipes in São Luiz and 60 of Melipona scutellaris in Uberlândia for biological studies. Dr. David de Jong read the ms and gave suggestions both in the text and in the English.

\section{REFERENCES}

DARWIN, C., 1859, The origin of species. The Menton Edition, 1958, New York, pp. 242-250.

KERR, W. E., CARVAlHO, G. A. NASCIMENTO, V. A., 1996, Abelha uruçu, biologia, manejo e conservação. Fundação Acangaú, Belo Horizonte, MG, Brasil, 144p.

MEINHARDT, H., 1995, A beleza matemática das conchas. Ciência e Cultura, 20: 28-36.

VOGT, H., 1911, Geometrie und Okonomie der BienenzellBreslau: Trewendt und Granier. (Translated to English by Miss A. Nossen \& W.M. Dutton. Library Service no . E 900 of the Int. Bee Res. Association). 